\title{
Współczesne postulaty unowocześnienia Kościoła i ich relewancja
}

$\mathrm{O}$ d dłuższego czasu mówi się o kryzysie Kościoła katolickiego, zwłaszcza w Europie Zachodniej. Świadczą o tym takie fenomeny, jak malejąca liczba wiernych uczestniczących w niedzielnej Mszy Świętej, stale zmniejszająca się ilość alumnów w seminariach duchownych czy też doniesienia o nadużyciach seksualnych popełnionych przez kapłanów i zakonników. Pojawiają się głosy, iż Kościół dotknął kryzys, ponieważ jest za mało ludzki i życiowy, zbyt mocno skupia się na sobie, a jego myślenie i działanie charakteryzuje skostniałość i konserwatyzm. Wszystko to sprawia, że coraz bardziej traci kontakt z rzeczywistością i irytuje opinię publiczną swoją postawą, zwłaszcza że zamiast być dla innych, przesadnie troszczy się o swój stan posiadania i prestiż w społeczeństwie.

Krytycy Kościoła - niezależnie od tego, czy są katolikami, czy nie - w swoich ocenach dają wyraz swemu niezadowoleniu zarówno z sytuacji, jaka panuje w łonie Kościoła, jak również z jego postawy względem świata. Ich krytyczne opinie mogą być pochodną pewnych resentymentów albo osobistych doświadczeń z Kościołem. Negatywne podejście do Kościoła może być także skutkiem przyjęcia pewnych pozakościelnych kryteriów, które stają się punktem odniesienia dla wydawania opinii na jego temat i sugerowania mu kierunku działań służących udoskonaleniu jego struktur oraz podejmowanych przez niego działań.

W niniejszym artykule zostaną najpierw ukazane główne motywy współczesnej krytyki Kościoła, a następnie typowe dla dzisiejszych czasów trendy światopoglądowe, przyczyniające się do negatywnej oceny obecności i działania Kościoła katolickiego w świecie. Rozpoznanie społeczno-ideowych czynników wywołujących u ludzi niezadowolenie z Kościoła prowadzi do refleksji nad sposobami odnowy jego życia i działalności duszpasterskiej. Odnowa ta jednak

\footnotetext{
Ryszard Hajduk CSsR - Uniwersytet Warmińsko-Mazurski; e-mail: reich-hart@wp.pl
} 
dopiero wtedy przyniesie pożądane owoce, jeśli uwzględniona w niej zostanie nauka o jego tajemnicy i zbawczym posłannictwie w świecie.

\section{1. „Zacofany Kościół” w nowoczesnej rzeczywistości}

Krytycy Kościoła dostrzegają jego braki zarówno w niezdolności do podejmowania reform wewnętrznych, jak i w jego małej skuteczności ewangelizacyjnej. Jedną z najważniejszych przyczyn kryzysu Kościoła ma być jego przesadna koncentracja na swoich strukturach organizacyjnych ${ }^{1}$. W XIX wieku z potęgi feudalnej, balansującej pomiędzy decentralistyczną strukturą episkopalną a mniej lub bardziej fikcyjnym centralizmem Kościół przekształcił się w wielką, odgórnie kierowaną, zbiurokratyzowaną organizację. Jej przydatność i sprawność mierzona jest zgodnie z tym, na ile pozwala swoim członkom realizować wytyczone przez siebie cele. $Z$ uwagi na troskę o profesjonalne działanie Kościoła powstają sformalizowane struktury zarządzania, mające czuwać nad jego sprawnym funkcjonowaniem. W takiej sytuacji, gdy ważniejsze staje się zarządzanie aniżeli to, co mówi Bóg, Kościół przestaje należycie wypełniać swoją misję².

Zdaniem niektórych krytyków Kościoła, najbardziej dotyka go dzisiaj kryzys organizacyjny ${ }^{3}$. Kościelne struktury nie są dostosowane do współczesności. Przypominają one muzeum, które obraca się w gruzy. Skostniałość struktur uniemożliwia Kościołowi właściwe postrzeganie rzeczywistości ${ }^{4}$. Ponadto Kościół bardziej koncentruje się na tradycji historycznej aniżeli na integracji współczesnych poglądów w swoje nauczanie i praktykę. Brak reformy struktur sprawia, że jako instytucja staje się on ludziom coraz bardziej niepotrzebny ${ }^{5}$.

W oczach krytyków wiele do życzenia pozostawiają wewnętrzne układy w Kościele. Władza jest w nim scentralizowana i znajduje się ręku małej grupy. Za decyzje Watykanu nikt personalnie nie odpowiada, gdyż wszystko dokonuje się w tajemnicy. Administracja kościelna faworyzuje karierowiczów, którzy dostosowują się do prądów panujących w Kościele. $\mathrm{Z}$ tego też powodu brakuje w nim odpowiednich przywódców, którzy byliby gotowi przeprowadzić konieczne reformy. Wciąż też nie ma dostatecznej otwartości na współpracę

${ }^{1}$ M.H. Crosby, Repair My House. Becoming a „Kingdom” Catholic, Maryknoll 2012, s. VII.

${ }^{2}$ U. Kuhnke, Zur theologischen Rekonstruktion der Identität christlicher Gemeinde, Düsseldorf 1992, s. 32; L. Mödl, Wenn’s ums Überleben geht, „Klerusblatt” 2004, nr 84, s. 198.

3 A. Dubach, Die Communio-Ekklesiologie - eine zeitadäquate Konzeption von Kirche?, w: Communio - Ideal oder Zerrbild von Kommunikation?, red. B.J. Hilberath, Freiburg i. B. 1999, s. 54; B. Hoban, Change or Decay. Irish Catholicism in Crisis, Dublin 2004, s. 26; M.H. Crosby, Repair My House..., p. 68.

${ }^{4}$ K.P. Fischer, Kirchenkrise und Gotteskrise. Katholische Kirche zwischen Vergangenheit und Zukunft, Berlin 2012, s. 3.

${ }^{5}$ T. Flannery, Keeping the Faith. Church of Rome or Church of Christ?, Cork 2005, s. 21-26. 
wiernymi świeckimi, a najważniejszą rolę w Kościele stale odgrywają duchowni (tzw. clerical church) ${ }^{6}$.

Jednym z zarzutów formułowanych pod adresem Kościoła jest krępowanie swobody wypowiedzi. Dowodem na to ma być fakt, że w Kościele działa nadal inkwizycja, która wprawdzie dzisiaj nazywa się inaczej, ale jej sposób funkcjonowania pozostaje niezmienny ${ }^{7}$. Wierni są uciskani przez hierarchię, która domaga się od nich posłusznego wypełniania jej poleceń. To samo odnosi się do duchownych i teologów, którzy są zobowiązani w swoich publikacjach i wystąpieniach na ambonie bronić głoszonych przez Kościół prawd i nie kolportować swoich prywatnych opinii. Taki stan rzeczy sprawia, że kaznodzieje mają trudność z jednoznacznym określeniem własnego stanowiska, co z kolei czyni ich przepowiadanie bezbarwnym i nieprzekonywającym ${ }^{8}$.

Współczesnemu Kościołowi zarzuca się, że więcej wagi przywiązuje do prawa i definicji katechizmowych niż do nauki Pisma Świętego. Ponadto powtarzanie treści dogmatycznych ustalonych w innych epokach nie służy dzisiejszemu człowiekowi pomocą w poszukiwaniu Boga. Tego rodzaju sformułowania należą do kultury przednaukowej, właściwej dla heteronomicznie myślącej kultury i tylko w jej obszarze mają znaczenie. $Z$ tego też względu nie mogą być uznane za absolutne i wieczne. Prawda niejedną ma twarz, gdyż doświadczenie ludzkie może być ujęte w różny sposób, a współczesny człowiek domaga się autonomii w uznawaniu tego, co jest słuszne, a co nie ${ }^{9}$.

Niezadowolenie krytyków Kościoła budzi tematyka poruszana w jego nauczaniu. Drobiazgowo rozpatrywane są w nim bowiem problemy dotyczące etyki seksualnej, a nie porusza się kwestii dopuszczenia kobiet do święceń kapłańskich, zniesienia celibatu ani sytuacji najuboższych i wykluczonych. Zamiast teologii ludu Bożego, otwartej na „znaki czasu”, preferowana jest eklezjologia skupiona na wewnętrznych sprawach Kościoła, promująca jego nieomylność. Dlatego sami katolicy tracą wiarę w Kościół instytucjonalny, nie będąc w stanie zrozumieć sensu jego istnienia i nauczania. Wszystko to sprawia, że Kościół i jego doktrynę dotyka kryzys autorytetu. Ludzie już nie przejmują się jego nauczaniem, dokonując swobodnych wyborów w sferze wiary i moralności ${ }^{10}$.

${ }^{6}$ B. Hoban, Change or Decay..., s. 25; T. Flannery, Keeping the Faith..., s. 29.

7 T. Flannery, Keeping the Faith..., s. 27.

${ }^{8}$ E. Flügge, Der Jargon der Betroffenheit. Wie die Kirche an ihrer Sprache verreckt, München 2016, s. 49.

${ }^{9}$ R. Lenaers, Der Traum des Königs Nebukadnezar. Das Ende einer mittelalterlichen Kirche, Kleve 2010, s. 28.

${ }^{10}$ B. Hoban, Change or Decay..., s. 25; C.E. Braaten, Mother Church. Ecclesiology and Ecumenism, Minneapolis 1998, s. 67; F.-X. Kaufmann, Kirchenkrise. Wie überlebt das Christentum?, Freiburg 2011, s. 138-139. 
Krytycy Kościoła katolickiego podkreślają, że działalność ewangelizacyjna Kościoła cierpi z powodu braku przełożenia Ewangelii na język współczesnych ludzi ${ }^{11}$. Przepowiadanie nie dociera do słuchaczy, gdyż Kościół odwołuje się w nim do światopoglądu i obrazu człowieka, typowych dla średniowiecza. Tymczasem nowoczesne społeczeństwa już dawno oddaliły się od kultury średniowiecznej. W odbiorze dzisiejszych słuchaczy komunikacja kościelna jest bezbarwna; nie budzi zdziwienia, nie irytuje, nie przeraża. Głosiciele słowa Bożego posługują się przestarzałymi formami językowymi, niezrozumiałymi dla słuchaczy ${ }^{12}$. Ponadto wielu mówców kościelnych zabiera głos, żeby mówić o czymś, do czego nie ma przekonania. Ktoś taki, kto inaczej żyje i inaczej mówi, nie będzie w stanie innych przyciągnąć do chrześcijaństwa ${ }^{13}$.

W opinii krytyków Kościół jako instytucja nie pasuje do dzisiejszej rzeczywistości, gdyż propaguje przestarzałe wzorce życiowe, w których ważne miejsce zajmuje wstrzemięźliwość seksualna w czasie narzeczeństwa, wierność małżeńska i wychowanie uwzględniające tradycyjne wartości ${ }^{14}$. Za niepożądane uważa się zaprzęganie państwowego systemu prawnego do realizacji kościelnych wskazań etycznych, a także powoływanie się na doktrynę chrześcijańską w ocenie rozstrzygnięć społeczno-politycznych. Krytycy Kościoła zarzucają mu, że nie chce uznać pełnej wolności człowieka, wskutek czego próbuje wywierać na ludzi nacisk, krępować ich samodzielne myślenie i ukrywać prawdę, zwłaszcza prawdę o Jezusie, o Bogu, o ludziach i o własnej historii ${ }^{15}$. Jego działanie ma znamiona fundamentalizmu oraz totalitaryzmu, a także cechuje się rygoryzmem i zachłannością. Wszystko to odpycha ludzi i skłania ich do apostazji ${ }^{16}$.

Kościół skoncentrowany na zabezpieczeniu swojego stanu posiadania oraz umacnianiu swojej pozycji w państwie i społeczeństwie wysuwa na pierwszy plan kwestie prawne, formalne, organizacyjne i urzędowe. Bardziej zainteresowany jest swoim przetrwaniem aniżeli życiem świata. Dlatego coraz mniej rozumie ludzi i nie wywiera już na nich żadnego wpływu ${ }^{17}$. Ponadto próbując pouczać ludzi w kwestiach moralnych, Kościół traci swój autorytet w sferze publicznej. W czasach, gdy ludziom nie potrzeba moralizowania, Kościół naraża się na odrzucenie, demonstrując wobec innych swoją moralną wyższość ${ }^{18}$.

${ }^{11}$ R. Lenaers, Der Traum des Königs Nebukadnezar..., s. 10-14,

${ }_{12}$ M. Kehl, Kirche in der Fremde. Zum Umgang mit der gegenwärtigen Situation der Kirche, w: Wozu Kirche? Wozu Gemeinde? Kirchenvisionen, red. G. Koch, J. Pretscher, Würzburg 1994, s. 52.

${ }^{13}$ E. Flügge, Der Jargon der Betroffenheit..., s. 48.

${ }^{14}$ R. Holloway, Doubts and Loves. What is Left of Christianity, Edinburgh 2001, s. 15.

${ }^{15}$ M. Kehl, Kirche in der Fremde..., s. 50.

16 D. Pauluk, Kościół katolicki na łamach „Gazety Wyborczej”, „Arcana” 1999, nr 1, s. 153-154.

${ }_{17}$ M. Albus, Kirche nach dem Infarkt. Von der Zukunft der Religion, Gütersloh 2007, s. 90.

${ }_{18}$ B. Reichert, Der Glaube in einer pluralen Welt. Zur gesellschaftlichen und politischen Wirksamkeit des Christlichen, „Entschluss” 1999, nr 2, s. 25; R. Bucher, Mehr als Stellschrauben, „Herder Korrespondenz” 2016, nr 6, s. 15. 


\section{Kierunki odnowy katolicyzmu w opinii krytyków Kościoła}

Katolicy i ich obecność w sferze publicznej traktowane są jako zagrożenie dla demokracji i procesów służących modernizacji życia społecznego, gdyż Kościół powołujący się w swej działalności na niezmienne prawo Boże wprowadza dysonans w funkcjonowanie życia społecznego. W dzisiejszych czasach, w których ludzie pragną robić nieograniczony użytek ze swej wolności, a nieomylność przypisywana jest demokratycznej większości, stanowiącej prawo ${ }^{19}$, powoływanie się na jakieś historyczne symbole i obstawanie przy dawnych normach etycznych wydaje się niezrozumiałe. Współczesny człowiek nie chce być kołem zębatym w maszynie sterowanej przez kogoś z zewnątrz. Absolutyzowana jest wolność podejmowania decyzji przez jednostki, czego skutkiem jest odrzucenie wielkich instytucji i norm społecznych, które zdają się zagrażać jej swobodzie ${ }^{20}$. Równocześnie jednak Kościół znajduje akceptację w nowoczesnym społeczeństwie, gdy pomaga ludziom zaspokoić ich potrzeby, zwłaszcza estetyczne i emocjonalne. W tym kontekście mówi się o „modernizacji” religijności, która nie zanika, ale podlega indywidualizacji i subiektywizacji, a to oznacza, że jednostka ludzka staje się w pełni odpowiedzialną za jej kształt i korzysta z posługi Kościoła wtedy, kiedy chce ${ }^{21}$.

W związku ze zmianą podejścia ludzi współczesnych do życia religijnego funkcjonowanie Kościoła i jego struktury winny zostać także zmodernizowane. Historia i należące do niej formy organizacyjne nie są już dzisiaj ludziom potrzebne; co więcej - należy zerwać z przeszłością i zwrócić się ku przyszłości, wprowadzając wszędzie to, co uznawane jest za postępowe. Jest to coś bezwzględnie koniecznego, zwłaszcza że nowoczesność uznawana jest za synonim dobra $^{22}$. Dlatego krytycy Kościoła sugerują, by dokonać w nim demokratyzacji struktur, zdeklerykalizować zarządzanie i we wszystkich wymiarach jego życia i działania egzekwować zasadę równouprawnienia płci²3. Tylko wtedy Kościół przestanie być odbierany jako muzeum obracające się w ruinę i będzie w stanie dostosować się do nowoczesnego przeżywania religijności.

Modernizacja życia i struktur Kościoła musi iść w parze z nowym podejściem do nauki katolickiej, głoszonej ludziom od wieków. Krytycy sugerują, by kato-

${ }_{19}$ J. Ratzinger, Was die Welt zusammenhält. Vorpolitische moralische Grundlagen eines freiheitlichen Staates, w: Dialektik der Säkularisierung. Über Vernunft und Religion, J. Habermas, J. Ratzinger, Freiburg i. B. 2006, s. 43.

${ }^{20}$ R. Inglehart, Modernisierung und Postmodernisierung, Frankfurt a. M. 1998, s. 48.

${ }^{21}$ P.L. Berger, Facing up to Modernity. Excursions in Society, Politics, and Religion, New York 1977, s. 190; K. Gabriel, Christentum zwischen Tradition und Postmoderne, Freiburg i. B. 1992, s. 142-145.

${ }_{22}$ B. Hałaczek, Postmodernizm rejestracją współczesności, „Studia Philosophiae Christianae” 1999, nr 2, s. 69; R. Inglehart, Modernisierung und Postmodernisierung..., s. 42.

${ }^{23}$ F.-X. Kaufmann, Kirchenkrise. Wie überlebt das Christentum?..., s. 139-148; B. Hoban, Change or Decay..., s. 26. 
licy zrezygnowali z przekonania, że niosą światu prawdę. Wszelkiego rodzaju występowanie z pozycji „posiadaczy” i głosicieli prawdy rodzi bowiem sprzeciw u współczesnych odrzucających możliwość jej poznania. Ponadto prawda objawiona, obiektywna i absolutna przymusza do jej przyjęcia, a tym samym stanowi zagrożenie dla ludzkiej wolności. Kościół musi zdać sobie sprawę z tego, że dla współczesnych ludzi prawda to nie definicje formułowane archaicznym językiem z powoływaniem się na Bożą interwencję. Prawda jest bowiem związana $\mathrm{z}$ autentycznością, $\mathrm{z}$ wartościami egzystencjalnymi, z głębią, wzbogaceniem życia i to jednostka ostatecznie decyduje o tym, co uzna za prawdziwe ${ }^{24}$.

W obecnych czasach sugeruje się Kościołowi katolickiemu, by zrezygnował z proklamacji Ewangelii i przestarzałej, obcej ludziom nauki, a włączył się w dialog, który dzisiaj zastępuje poszukiwanie prawdy ${ }^{25}$. Powinien to być dialog angażujący urząd nauczycielski Kościoła, teologię, doświadczenie życiowe i kształtowanie ludzkiej egzystencji. Musi być w nim także miejsce na wyniki badań prowadzonych w obszarze nauk przyrodniczych, które stanowią istotny składnik świadomości współczesnych ludzi ${ }^{26}$. Ponadto najważniejszą zasadą $\mathrm{w}$ jego prowadzeniu winna być tolerancja rozumiana jako afirmacja dla odmiennych poglądów i przyzwolenie na wyrażanie wszelkiego rodzaju emocji, doznań i opinii. W przeciwnym razie Kościół może zostać posądzony o wywieranie nacisku na otoczenie, o nieposzanowanie wolności osoby ludzkiej i o brak akceptacji dla pluralizmu uważanego za jedną z najistotniejszych wartości.

Kościół jawi się jego krytykom jako instytucja niepasująca do dzisiejszej rzeczywistości społecznej, gdyż jest nazbyt centralistyczna i opresyjna w stosunku do swoich członków. Szansę na zmianę upatrują w zaprowadzeniu w niej „kultury wolnego słowa”27. W ich mniemaniu swobodne wygłaszanie opinii przez wierzących oraz niczym nieskrępowane podejmowanie rozstrzygnięć doktrynalno-pastoralnych pozwoli Kościołowi stać się organizacją pluralistyczną i otwartą, która tylko w wyjątkowych sytuacjach ingeruje w działalność lokalnych struktur i jednostek.

Krytycy Kościoła dostrzegają problemy z przekazem wiary pojawiające się zwłaszcza wtedy, gdy jego adresatami są ludzie spoza wspólnoty kościelnej ${ }^{28}$. Ich zdaniem, nie poprawi wówczas sytuacji sama zmiana języka z abstrakcyjnego, teologicznego na konkretny i bliski współczesnym ludziom. Potrzeba nowego

24 R. Lenaers, Der Traum des Königs Nebukadnezar..., s. 27.

25 I. Ziemiański, Postmodernizm a dylematy człowieka, „Etos” 1996, nr 1/2, s. 142.

26 R. Inglehart, Modernisierung und Postmodernisierung..., s. 471; B. Reichert, Der Glaube in einer pluralen Welt..., s. 26.

${ }^{27}$ F.-X. Kaufmann, Kirchenkrise. Wie überlebt das Christentum?..., s. 150; R. Hajduk, Schwächen oder Stärken des heutigen Katholizismus? Kritische Bemerkungen zu einer Kritik an der Kirche, „Studia Redemptorystowskie” 2015, nr 13, s. 236-237.

${ }^{28}$ E. Flügge, Der Jargon der Betroffenheit..., s. 91. 
podejścia do przekazywanych treści, a to oznacza, że Kościół w swej proklamacji winien skoncentrować się na sprawach priorytetowych, ukazując światu, co jest istotą wiary chrześcijańskiej. Nie wolno mu rozmieniać się na drobne, zabierając głos w każdej kwestii. Winien także pamiętać, że religia zaczyna się "psuć, gdy mówi tylko o problemach moralnych ${ }^{29}$.

Od kościelnej komunikacji oczekuje się, iż docenione w niej zostaną takie wartości obecne we współczesnej kulturze, jak tolerancja równoznaczna $\mathrm{z}$ akceptacją istnienia innych jako innych i wolna od zaborczości oraz jakichkolwiek nacisków, poszanowanie sumienia jako ostatniej instancji w podejmowaniu decyzji moralnych, docenienie komunikacji i partycypacji we wszystkich procesach, obejmujących jednostki, społeczeństwo i środowisko, dążenie do wolności i samostanowienia w kształtowaniu życia osobistego. Tego rodzaju wartości w ostatnich wiekach chrześcijaństwa tylko w jakimś niewielkim stopniu były obecne w Kościele ${ }^{30}$. Dzisiaj zaś będzie on uważany za tradycjonalistyczne getto we współczesności, jeśli nie zgodzi się na pluralizm pośród form egzystencji, światopoglądów oraz aksjologii i nie pozostawi ludziom pełnej odpowiedzialności za dokonywane wybory życiowe.

Niektórzy krytycy Kościoła są zdania, że jeśli ma on znaleźć współcześnie uznanie w społeczeństwie, jego aktywność w świecie winna w zasadzie ograniczyć się do podejmowania działań na rzecz dobra wspólnego. Kościół zyskuje na znaczeniu, gdy ludzie mają wymierną korzyść z jego obecności w świecie. Szczególnie ważne jest umacnianie ładu społecznego oraz podejmowanie dzieł charytatywnych, przyczyniających się do zaspokajania najważniejszych ludzkich potrzeb materialnych i psychicznych ${ }^{31}$.

Funkcja Kościoła jako kompasu w dokonywaniu wyborów etycznych okazuje się dzisiaj nie aż tak istotna. Poczucie zabezpieczenia materialnego, które charakteryzuje społeczeństwa wysoko rozwinięte, zmniejsza potrzebę propagowania klarownych reguł współżycia międzyludzkiego. Ludzie niepewni swojego losu, żyjący w wielkim stresie poszukują jasno określonych reguł działania w społeczności. Muszą wiedzieć, jak postąpić, gdy znajdą się w niebezpieczeństwie. Jako że nie mogą sobie pozwolić na jakieś poważne błędy, potrzeba im jednoznacznych wskazań, zapewniających dotarcie do celu. Tymczasem gdy ludzie czują się w dużym stopniu zabezpieczeni materialnie i wolni od poważnych zagrożeń, mogą tolerować różnorodność w świecie wartości i reguł moralnych. Wówczas też mniej potrzeba im zasad religijnych, a obecność Kościoła w świecie może ograniczyć się do troski o biednych i potrzebujących wsparcia ${ }^{32}$.

\footnotetext{
${ }^{29}$ B. Reichert, Der Glaube in einer pluralen Welt..., s. 25.

${ }^{30} \mathrm{M}$. Kehl, Kirche in der Fremde..., s. 45.

${ }^{31}$ G. Danneels, Kościół w ogniu krytyki, „Pastores” 2003, nr 2, s. 50-51.

32 R. Inglehart, Modernisierung und Postmodernisierung..., s. 63.
} 
Traktowanie Kościoła jako instytucji wspierającej państwo w trosce o godną egzystencję swoich obywateli odpowiada typowej dla obecnych czasów ekonomizacji życia ludzkiego. W społeczeństwie popularyzującym takie myślenie na uznanie zasługuje ten, kto wnosi wymierny wkład w dobrobyt społeczeństwa. Pod tym kątem oceniany jest także Kościół, który znajduje tym więcej akceptacji w opinii publicznej, im bardziej pożyteczna jest jego działalność dla jednostek i całego środowiska ${ }^{33}$.

\section{W poszukiwaniu odpowiedzi na zarzuty pod adresem współczesnego Kościoła}

Refleksja nad motywami krytycznego podejścia do Kościoła oraz poszukiwanie kryterium dokonywania oceny jego funkcjonowania prowadzi do wniosku, że krytycy Kościoła są świadomi zmian zachodzących w dzisiejszej rzeczywistości i ulegają w jakiś sposób panującym w niej trendom filozoficznym i światopoglądowym. Ich osądy wynikają z przekonania, że Kościół nie nadąża za procesami transformacyjnymi, zachodzącymi zarówno w ludzkiej świadomości, jak i w życiu społecznym. Gdyby jednak spojrzeć na tę samą rzeczywistość z perspektywy teologicznej, można stwierdzić, że istnieje wyraźny rozdźwięk pomiędzy współczesną rzeczywistością a Ewangelią i głoszącym ją Kościołem ${ }^{34}$, którego zadaniem jest wnosić ducha Chrystusowego w życie świata i przekształcać ludzką rzeczywistość w cywilizację miłości. A zatem to nie dominujące w dzisiejszej kulturze prądy myślowe i ideologiczne winny być czynnikami transformującymi Kościół, lecz Ewangelia ma przyczyniać się do oczyszczenia kultury z tego wszystkiego, co zagraża ludzkiej godności i wspomagać jej pełny rozkwit dla dobra człowieka ${ }^{35}$.

Prawdą jest, iż również Kościół potrzebuje nieustannej przemiany i to w kontekście wyzwań pojawiających się przed nim w każdej nowej epoce historycznej i rozumianych jako „znaki czasu” ${ }^{36}$. Jej pierwszym bodźcem nie są jednak popularne $\mathrm{w}$ danej chwili poglądy filozoficzne ani zdobycze naukowe, lecz Boże Objawienie pozwalające dokonać właściwego rozeznania w rzeczywistości i odnalezienia w wydarzeniach, potrzebach i pragnieniach ludzkich "prawdziwe znaki obecności lub zamysłów Bożych"37. Jedynie w świetle prawdy objawionej

${ }^{33}$ L. Mödl, Wenn's ums Überleben geht..., s. 201.

${ }^{34} \mathrm{EN}$ nr 20.

${ }^{35}$ J. Ratzinger, Comunicazione e cultura: nuovi percorsi per l'evangelizzazione nel Terzo Millennio, „Nuova Umanità” 2003, nr 1, s. 48-49.

${ }^{36}$ K. Gabriel, Die Religion der Stunde? Anmerkungen zur Soziologie des gegenwärtigen Katholizismus, „Theologisch-Praktische Quartalschrift” 2013, nr 1, s. 19.

${ }^{37} \mathrm{KDK}$ nr 11. 
i w wierności swemu powołaniu Kościół może coraz pełniej odkrywać swoją istotę i misję, a tym samym kształtować swoją samoświadomość i uzyskiwać nowe impulsy do stawania się tym, czym $\mathrm{z}$ woli Bożej ma byćc ${ }^{38}$.

Wśród zagorzałych krytyków Kościoła jest wielu zaangażowanych katolików, a nawet duchownych, których bardziej przekonuje i pociąga aktualny model myślenia ludzi aniżeli przekazywana od wieków nauka Kościoła, oparta na słowie Bożym i Tradycji. Taki stan rzeczy domaga się od duszpasterzy podjęcia większego wysiłku w celu umocnienia tożsamości wierzących w Chrystusa, aby światło wiary kształtowało ich sposób patrzenia na rzeczywistość ${ }^{39}$. Służy temu zarówno katecheza, jak i tworzenie żywych wspólnot, w których wierni żyjący w komunii braterskiej już spotykają się z misterium Kościoła i „poznają je niejako doświadczalnie, w sposób odpowiadający ich naturze" ${ }^{" 40}$, zanim jeszcze wyrobią sobie jasno pojęcie o tej tajemniczej rzeczywistości. Wtedy też wierzący dają się przeniknąć Ewangelii, która pozwala im z Bożej perspektywy wszystko badać, a to, co szlachetne, zachowywać (por. 1 Tes 5,21). Dopiero wówczas osiągnięcia czasów współczesnych mogą służyć zdrowej odnowie życia Kościoła i jego funkcjonowania w świecie.

Krytycy Kościoła dopominają się o bardziej zrozumiały przekaz orędzia Chrystusowego, przy czym mają na myśli nie tylko formalną stronę komunikacji, ale także jej zawartość. Ich postulaty dotyczące reinterpretacji bądź odrzucenia pewnych treści mogłyby doprowadzić do zniekształcenia nauki chrześcijańskiej. Jeśli najważniejszym kryterium w głoszeniu Ewangelii jest współczesny człowiek, jego mentalność i potrzeby, pojawia się niebezpieczeństwo zagubienia istoty Bożego objawienia i podporządkowania jego przekazu pragnieniom ludzkim. Jakkolwiek Kościół ma służyć ludziom, to jednak jego pierwszą powinnością jest być sługą Boga i Jego prawdy, którą Stwórca pragnie przekazać człowiekowi ze względu na jego szczęście.

Nie ma wątpliwości, że każda epoka domaga się translacji prawd wiary na język zrozumiały dla żyjących w niej ludzi i takiego ich wykładu, aby mogły być przyjęte przez ich adresatów jako istotne, przekonywające i wzbogacające ich życie. Dlatego ważne jest, by Kościół miał świadomość, kim jest słuchający go człowiek i czego poszukuje. Bez popadania w niewierność względem Bożego Objawienia głosiciele Ewangelii winni ją tak ukazywać, aby ludzie widzieli w niej najlepszą propozycję na życie - drogę, na którą trzeba wstąpić, aby osiągnąć pełnię człowieczeństwa ${ }^{41}$. Kościołowi nie wolno ulec przekonaniu, że skoro oferuje ludziom Ewangelię, czyli „najlepszy z produktów”, nie musi już troszczyć

\footnotetext{
${ }^{38} \mathrm{DE}$ nr 6.

39 LF nr 18.

40 ES nr 37.

$41 \mathrm{SpS}$ nr 6.
} 
się o takie jego zaprezentowanie, by człowiek nie miał wątpliwości, że tego mu właśnie najbardziej potrzeba ${ }^{42}$.

Krytykom kościelnej komunikacji wydaje się umykać jedna istotna kwestia: chrześcijaństwo nie jest religią ograniczoną do systemu definicji dogmatycznych i zasad moralnych, które przekazuje ludziom, aby poszerzyć ich spojrzenie na rzeczywistość i dać im użyteczne wskazówki życiowe. Gdy Kościół głosi słowo Boże, ukazuje Jezusa, a nawet Go uobecnia („wydarzenie Chrystusa”), by człowiek mógł nawiązać z Nim osobistą relację. Prawda głoszona przez chrześcijan jest osobą, która nie uciska i nie odbiera człowiekowi wolności, lecz go naprawdę wyzwala. To Jezus, którego bogactwa i piękna nie jest w stanie wyczerpać żadna epoka ${ }^{43}$, pozwala człowiekowi najpełniej siebie zrozumieć ${ }^{44}$ i najdoskonalej się rozwinąć ${ }^{45}$.

Prawdziwe życie jest spotkaniem, a prawdziwa komunikacja jest dialogiem. Dlatego - zgodnie z tym, co postulują krytycy Kościoła - wyznawcy Chrystusa winni uczestniczyć w dialogu, którego nie można jednak sprowadzić do wymiany myśli. Cel dialogu musi wykraczać poza życzliwe wsłuchiwanie się w czyjeś opinie czy odczucia. Kościół ma zadanie angażować się w dialog mający na względzie zbawienie człowieka, które osiąga przez poznanie i przyjęcie prawdy Ewangelii (por. Rz 1,16). Tylko taki dialog zbliża ludzi, któremu towarzyszy umiłowanie prawdy ${ }^{46}$. Zasada ta ma zastosowanie nie tylko w teologii i zbawczym posłannictwie Kościoła, lecz także na innych płaszczyznach komunikacji międzyludzkiej.

Kościół głosi słowo Boże z przekonaniem, że została w nim objawiona ludziom odwieczna i niezmienna prawda ${ }^{47}$. Z uwagi zaś na szeroko dzisiaj rozpowszechniony sceptycyzm co do możliwości poznania prawdy obiektywnej oraz szerzący się relatywizm dialog prowadzony przez Kościół winien służyć apologetyce, czyli ukazywaniu rozumności i prawdziwości wiary chrześcijańskiej. Praktykowana w dialogu apologetyka domaga się miłości i troski o interlokutorów. Nie oznacza to jednak konieczności rezygnowania z prawdy, ale staranie o to, by w odpowiedni sposób ją przekazać. Trzeba dawać świadectwo prawdzie, bez narzucania jej temu, kto nie chce jej przyjąć. Ukrywanie prawdy nie jest wyrazem miłości, lecz lęku. Im bardziej ktoś wierzy, że Jezus jest Panem i Zbawicielem, tym większe będzie jego zaangażowanie w głoszenie prawdy Ewangelii ${ }^{48}$.

Uwagi krytyczne formułowane pod adresem Kościoła odnoszą się często do jego roli w życiu publicznym i kończą się wysunięciem postulatów dotyczących

\footnotetext{
${ }^{42}$ W. Uranga, Comunicación, Iglesia y sociedad. Visión socio-eclesiológica de la comunicación, w: Evangelización y Comunicación, G. Ravasi, J. McDonnell, W. Uranga, Caracas 1994, s. 159.

${ }^{43}$ EG nr 11.

${ }^{44} \mathrm{RH}$ nr 10.

${ }^{45} \mathrm{KDK}$ nr 41.

${ }^{46} \mathrm{KDK}$ nr 92.

47 VD nr 19.

${ }^{48}$ G.B. Siniscalchi, Retrieving Apologetics, Eugene 2016, s. 5.
} 
jego użyteczności w zaspokajaniu potrzeb współczesnych ludzi. Bez wątpienia najważniejszą potrzebą człowieka jest doświadczenie bliskości, wsparcia i miłości. Tej też potrzebie Kościół zawsze wychodzi naprzeciw, przekazując ludziom niewzruszoną i nieskończoną miłość Bożą, która daje prawdziwą radość życia ${ }^{49}$. Jest to miłość uprzedzająca i niezawodna, której siłę człowiek odkrywa zwłaszcza wtedy, gdy spotyka się z obojętnością, pogardą i odrzuceniem ze strony bliźnich. Głoszeniu ludziom Boga, który jest miłością, towarzyszy zawsze zaproszenie do uczestnictwa we wspólnocie wierzących w Chrystusa, zjednoczonych ze sobą więzami miłości. Ci, którzy je przyjmą, przekonują się, iż Kościół to nie bezduszna, przestarzała instytucja, lecz dom ojcowski, braterski i gościnny, a miłość łącząca wierzących ,jest niezbywalnym wyrazem jego istoty" ${ }^{\prime 20}$.

Jest rzeczą oczywistą, iż Kościół obecny i działający w sferze publicznej - jak wszystkie inne instytucje i organizacje - może stać się obiektem krytyki. Tak też dzieje się, gdy podnoszone są głosy domagające się modernizacji struktur kościelnych, redefinicji jego nauczania, poprawy komunikacji i dostosowania działalności Kościoła do potrzeb środowiska. Uwagę zwraca fakt, iż krytycy katolicyzmu przy dokonywaniu jego oceny odwołują się do aktualnych trendów myślowych i procesów społecznych, zachodzących we współczesnym świecie. Kościół jest przez nich postrzegany przede wszystkim w perspektywie horyzontalnej jako instytucja i oceniany pod kątem jej dopasowania się do nowoczesnej rzeczywistości i przydatności dla ludzi. Jego pochodzenie od Boga oraz rola $\mathrm{w}$ dziele zbawienia właściwie nie są przez nich dostrzegane.

Bez wątpienia istnieje potrzeba krytycznego spojrzenia na Kościół i to w kontekście dzisiejszych przemian społecznych. Tak czyni papież Franciszek w adhortacji apostolskiej Evangelii gaudium. W tym wypadku jednak podstawowym punktem odniesienia jest powołanie Kościoła do głoszenia Dobrej Nowiny całemu światu, zgodnie z nakazem Zbawiciela. Zadaniem wspólnoty wyznawców Chrystusa jest dostosować struktury kościelne do potrzeb ewangelizacji, a także właściwie odczytać potrzeby współczesnych ludzi i wyjść im naprzeciw z orędziem o Bogu zawsze bezgranicznie miłującym człowieka.

Nie można reformować Kościoła, redukując go do jednej z wielu instytucji kształtujących życie publiczne. Jest to bowiem także sakrament zbawienia, lud Boży pielgrzymujący ścieżkami historii oraz communio - wspólnota ochrzczonych zjednoczonych z Bogiem przez Chrystusa w Duchu Świętym i pomiędzy sobą. Wszystko w Kościele ukierunkowane jest na Boga i wszystko ma w nim

49 EG nr 3.

${ }^{50}$ DCE nr 25; R. Hajduk, Ewangelia na forum świata. Od apologetyki do marketingu narracyjnego, Kraków 2013, s. 57. 
mówić o Bogu. Jego istnienie w świecie ma być podporządkowane jednemu: głosić ludziom „Boga, który objawił swoją ogromną miłość w Chrystusie umarłym i zmartwychwstałym” ${ }^{51}$ i prowadzić ich na „spotkanie z Osobą, która nadaje życiu nową perspektywę, a tym samym decydujące ukierunkowanie" ${ }^{52}$. Tylko wtedy, gdy Kościół przemienia się w świetle Chrystusowej prawdy i nie traci z oczu swej misji, może umacniać swoją tożsamość i wskazywać ludziom drogę wiodącą do zbawienia.

\section{Literatura}

Albus M., Kirche nach dem Infarkt. Von der Zukunft der Religion, Gütersloh 2007, s. 90.

Berger P.L., Facing up to Modernity. Excursions in Society, Politics, and Religion, New York 1977, s. 190.

Braaten C.E., Mother Church. Ecclesiology and Ecumenism, Minneapolis 1998, s. 67.

Bucher R., Mehr als Stellschrauben, "Herder Korrespondenz" 2016, nr 6, s. 15.

Crosby M.H., Repair My House. Becoming a "Kingdom" Catholic, Maryknoll 2012, s. VII-68.

Danneels G., Kościół w ogniu krytyki, „Pastores” 2003, nr 2, s. 50-51.

Dubach A., Die Communio-Ekklesiologie - eine zeitadäquate Konzeption von Kirche?, w: Communio - Ideal oder Zerrbild von Kommunikation?, red. B.J. Hilberath, Freiburg i. B. 1999, s. 54.

Fischer K.P., Kirchenkrise und Gotteskrise. Katholische Kirche zwischen Vergangenheit und Zukunft, Berlin 2012, s. 3.

Flannery T., Keeping the Faith. Church of Rome or Church of Christ?, Cork 2005, s. 21-29.

Flügge E., Der Jargon der Betroffenheit. Wie die Kirche an ihrer Sprache verreckt, München 2016, s. 48-91.

Gabriel K., Christentum zwischen Tradition und Postmoderne, Freiburg i. B. 1992, s. 142-145.

Gabriel K., Die Religion der Stunde? Anmerkungen zur Soziologie des gegenwärtigen Katholizismus, "Theologisch-Praktische Quartalschrift" 2013, nr 1, s. 19.

Hajduk R., Ewangelia na forum świata. Od apologetyki do marketingu narracyjnego, Kraków 2013, s. 57.

Hajduk R., Schwächen oder Stärken des heutigen Katholizismus? Kritische Bemerkungen zu einer Kritik an der Kirche, "Studia Redemptorystowskie” 2015, nr 13, s. 236-237.

Hałaczek B., Postmodernizm rejestracją współczesności, „Studia Philosophiae Christianae” 1999, nr 2, s. 69.

Hoban B., Change or Decay. Irish Catholicism in Crisis, Dublin 2004, s. 25-26.

Holloway R., Doubts and Loves. What is Left of Christianity, Edinburgh 2001, s. 15.

Inglehart R., Modernisierung und Postmodernisierung, Frankfurt a. M. 1998, s. 42-471.

Kaufmann F.-X., Kirchenkrise. Wie überlebt das Christentum?, Freiburg 2011, s. 138-150.

Kehl M., Kirche in der Fremde. Zum Umgang mit der gegenwärtigen Situation der Kirche, w: Wozu Kirche? Wozu Gemeinde? Kirchenvisionen, red. G. Koch, J. Pretscher, Würzburg 1994, s. 45-52.

Kuhnke U., Zur theologischen Rekonstruktion der Identität christlicher Gemeinde, Düsseldorf 1992, s. 32;

Lenaers R., Der Traum des Königs Nebukadnezar. Das Ende einer mittelalterlichen Kirche, Kleve 2010, s. 10-28.

Mödl L., Wenn's ums Überleben geht, "Klerusblatt” 2004, nr 84, s. 198-201.

Pauluk D., Kościół katolicki na łamach „Gazety Wyborczej”, „Arcana” 1999, nr 1, s. 153-154.

\footnotetext{
51 EG nr 11.

52 DCE nr 1 .
} 
Ratzinger J., Comunicazione e cultura: nuovi percorsi per l'evangelizzazione nel Terzo Millennio, „Nuova Umanità" 2003, nr 1, s. 48-49.

Ratzinger J., Was die Welt zusammenhält. Vorpolitische moralische Grundlagen eines freiheitlichen Staates, w: Dialektik der Säkularisierung. Über Vernunft und Religion, J. Habermas, J. Ratzinger, Freiburg i. B. 2006, s. 43.

Reichert B., Der Glaube in einer pluralen Welt. Zur gesellschaftlichen und politischen Wirksamkeit des Christlichen, „Entschluss” 1999, nr 2, s. 25-26.

Siniscalchi G.B., Retrieving Apologetics, Eugene 2016, s. 5.

Uranga W., Comunicación, Iglesia y sociedad. Visión socio-eclesiológica de la comunicación, w: Evangelización y Comunicación, G. Ravasi, J. McDonnell, W. Uranga, Caracas 1994, s. 159.

Ziemiański I., Postmodernizm a dylematy człowieka, „Etos” 1996, nr 1/2, s. 142.

\section{Skróty}

EN - Evangelii nuntiandi, Paweł VI, Adhortacja apostolska o ewangelizacji w świecie współczesnym, Rzym 1975.

KDK - Gaudium et spes, Sobór Watykański II, Konstytucja duszpasterska o Kościele w świecie współczesnym, Rzym 1965.

DE - Unitatis redintegratio, Sobór Watykański II, Dekret o ekumenizmie, Rzym 1964.

LF - Lumen fidei, Franciszek, Encyklika o wierze, Rzym 2013.

ES - Ecclesiam suam, Paweł VI, Encyklika o drogach, którymi Kościół katolicki powinien kroczyć w dobie obecnej przy pełnieniu misji, Rzym 1964.

SpS - Spe salvi, Benedykt XVI, Encyklika o nadziei chrześcijańskiej, Rzym 2007.

EG - Evangelii gaudium, Franciszek, O głoszeniu Ewangelii we współczesnym świecie, Rzym 2013.

RH - Redemptor hominis, Jan Paweł II, Encyklika o Odkupicielu człowieka, Rzym 1979.

VD - Verbum Domini, Benedykt XVI, Adhortacja apostolska o słowie Bożym w życiu i misji Kościoła, Rzym 2010.

DCE - Deus caritas est, Benedykt XVI, Encyklika o miłości chrześcijańskiej, Rzym 2005.

\section{Streszczenie}

W dzisiejszych czasach Kościół katolicki staje się często przedmiotem surowej krytyki. Zarzuca mu się anachroniczność i skostniałość struktur organizacyjnych, krępowanie wolności słowa, propagowanie przestarzałych wzorców życiowych i kultury przednaukowej, totalitaryzm i zachłanność. Krytycy Kościoła formułują także postulaty jego odnowy, wzywając do modernizacji struktur, zdefiniowania na nowo kościelnej doktryny, udoskonalenia przekazu treści wiary oraz dostosowania działalności do oczekiwań społecznych. Wskazując Kościołowi kierunki transformacji, odwołują się do modnych dzisiaj poglądów (filozoficznych) i dokonujących się w świecie procesów społecznych. Pomijają przy tym fakt, że Kościół jest „Bożą budowlą” i nie można dokonać jego reformy bez odniesienia do słowa Bożego i Tradycji. Kościół zaś może prawdziwie odnawiać się tylko mocą Ewangelii i w wierności misji powierzonej mu przez Jezusa Chrystusa.

Słowa kluczowe: katolicyzm, eklezjologia, społeczeństwo, doktryna, ewangelizacja, duszpasterstwo. 


\section{Contemporary Postulates of the Modernization of the Church and their Relevance}

\section{Summary}

Nowadays, the Catholic Church is often the subject of severe criticism. It is accused of being an anachronism, ossificating of organizational structures, limiting freedom of speech, propagating outdated life patterns and pre-scientific culture, totalitarianism and greed. The Church's critics also formulate demands for its renewal, calling for the modernization of structures, the redefinition of ecclesiastic doctrine, the refinement of the communication of the content of faith and the adaptation of activities to social expectations. B y indicating the Church the directions of transformation, they refer to current trendy (philosophical) views and social processes taking place in human reality. They also ignore the fact that the Church is "God's building" and that it cannot be reformed without reference to the Word of God and tradition. The Church can truly be renewed only by the power of the Gospel and by faithfulness to the mission entrusted to him by Jesus Christ.

Keywords: Catholicism, ecclesiology, society, doctrine, evangelization, pastoral care. 